\title{
A standard area diagram set for assessing severity of eucalyptus bacterial blight caused by Erwinia psidii
}

\section{Uma escala diagramática para a avaliação da severidade da seca-de-ponteiros do eucalipto causada por Erwinia psidii}

Norton Borges Junior ${ }^{1 *}$ (D) (https://orcid.org/0000-0003-1913-7405)

Alexandre Sandri Capucho² (iD (https://orcid.org/0000-0003-1002-9969)

Roberto Lanna Filho3 (D) (https://orcid.org/0000-0003-2359-2806)

\begin{abstract}
This study aimed to develop and validate a standard area diagram (SAD) set to estimate the severity of bacterial blight of eucalyptus caused by Erwinia psidii. For this purpose, an eightlevel SAD was developed and validated by ten inexperienced raters. Accuracy and precision of the estimates by each rater, with and without the SAD, were determined based on Lin's concordance correlation coefficient. The proposed SAD improved the accuracy and precision of the estimates. The SAD set studied here is a useful tool in assessments of bacterial blight of eucalyptus for epidemiological research and breeding programs.
\end{abstract}

KEYWORDS: disease scale; disease severity; disease assessment; epidemiology.
RESUMO: Este trabalho objetivou o desenvolvimento de uma escala para estimar a severidade da seca-de-ponteiros do eucalipto causada por Erwinia psidii. Para isso, uma escala de oito níveis foi desenvolvida e validada por dez avaliadores inexperientes. A acurácia e precisão das estimativas de cada avaliador, com e sem a escala, foram determinadas baseadas no coeficiente de correlação concordante de Lin. A escala proposta melhorou a acurácia e a precisão das estimativas. A escala estudada se mostrou uma ferramenta útil na avaliação da seca-de-ponteiros do eucalipto para estudos epidemiológicos e em programas de melhoramento.

PALAVRAS-CHAVE: escala de doença; severidade da doença; avaliação de doenças; epidemiologia. 
Bacterial blight is the most important emergent disease of eucalyptus in Brazil (MONTOYA-ESTRADA et al., 2019). Production losses can reach $30 \%$ in forests planted with susceptible genotypes. The disease is caused by the plant-pathogenic bacterium Erwinia psidii (RODRIGUES NETO et al., 1983), which colonizes the xylem vessels and parenchymal intercellular spaces (CHAI et al., 2017; CAIRES et al., 2020). Besides affecting eucalyptus, the pathogen can cause serious damage to guava and papaya crops in tropical and subtropical conditions (RODRIGUES NETO et al., 1983; COUTINHO et al., 2011; CHAI et al., 2017). The main symptoms caused by the bacterium on eucalyptus are dieback, leaf hydrosis (i.e., water-soaking) close to midrib, stem canker and wilt (COUTINHO et al., 2011; ARRIEL et al., 2014; SILVA et al., 2016; MACAGNAN; FERREIRA, 2018). Disease quantification is based on visual observation, which makes the disease assessment inaccurate and/or imprecise and might lead to faulty conclusions being drawn from the data. This can lead to incorrect actions in disease management programs.

The use of a standard area diagram (SAD) set for bacterial blight is a way to obtain greater objectivity (reliability, precision, and accuracy) in disease assessment on eucalyptus trees under
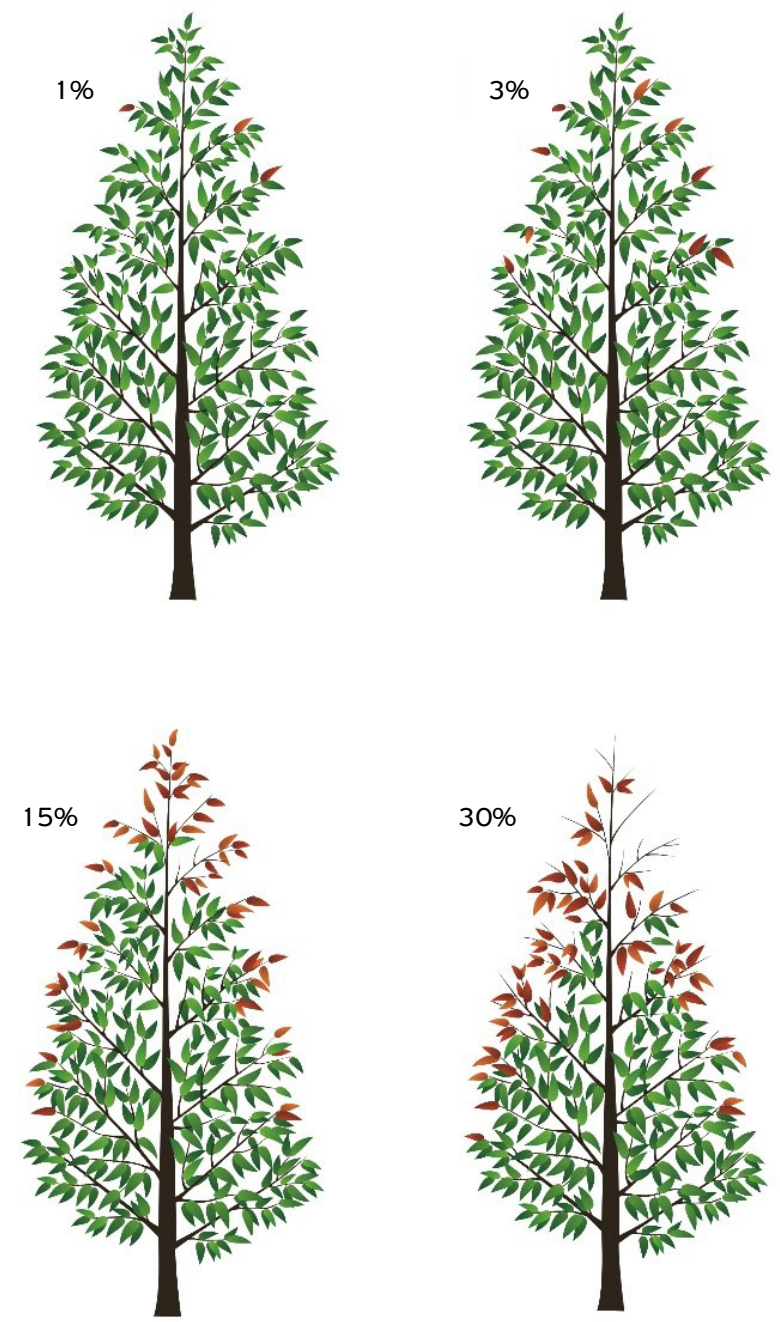

field conditions. Besides, assessments using SADs are fast and do not require equipment because they allow for raters' training (BOCK et al., 2010; 2016; ARAÚJO et al., 2019). The rapid quantification of the severity of bacterial blight is essential to select elite disease-resistant genotypes in field research. This is because the disease can manifest itself on eucalyptus trees up to 2 years old (COUTINHO et al., 2011), under field conditions. In this context, the development and validation of a SAD set are reported to estimate the severity of bacterial blight on eucalyptus trees.

For the development of the scale, 80 images were taken of plants from a clone of Eucalyptus grancam (Eucalyptus grandis $\times$ Eucalyptus camaldulensis) $\times$ Eucalyptus urophylla, which presented the greatest range of disease symptoms. The plants were photographed at $4 \mathrm{~m}$ of distance against a white background, using a Canon SX50 digital camera, in a one-year-old plantation located in the municipality of Eldorado do Sul, state of Rio Grande do Sul, Brazil. The QUANT program (VALE et al., 2003) was used to determine the real disease severity in the images, based on the proportion of diseased plant tissue (leaves and branches). The SAD set was proposed with the following severity levels: 1, 3, 5, 10, 15, 30, 50 and $100 \%$ (Fig. 1).
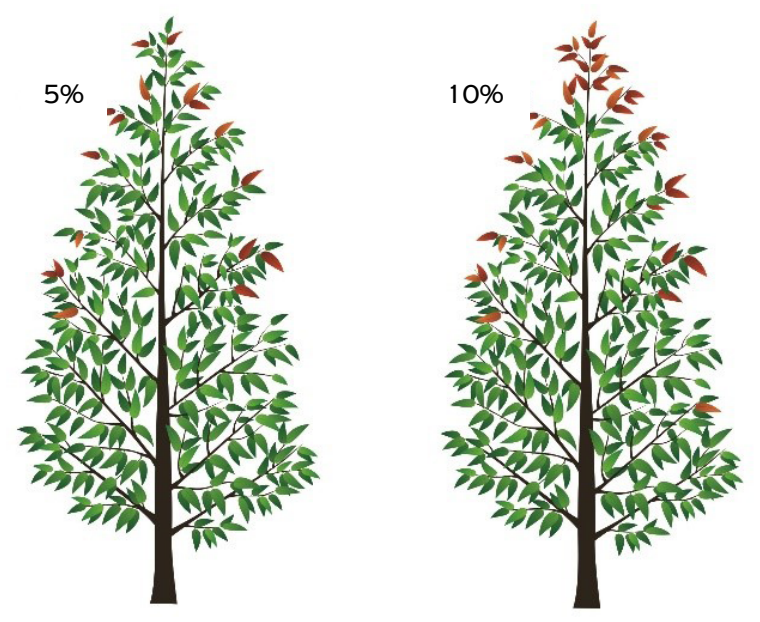

Figure 1. Standard area diagram (SAD) set for bacterial blight (Erwinia psidii) severity on eucalyptus trees (Eucalyptus grancam $\times$ Eucalyptus urophylla). Data are represented as the percentage (\%) of leaf and branch area with bacterial blight symptoms. 
In order to validate the scale, ten raters without experience quantified the disease severity using images of the plants, which were shown to them individually using a file in Power Point. In the first validation step, the raters made estimates of disease severity using the images of 40 plants with disease symptoms, without using the scale. In the second step, the same raters analyzed another 40 images, but this time using the proposed scale. To determine the accuracy and precision of the estimates of disease severity by each rater, with and without the use of the SAD set, Lin's concordance correlation coefficient analysis was used, with the help of the SAS 9.0 program (SAS Institute Inc., Cary, NC, USA), as previously described (DOLINSKI et al., 2017).

Based on Lin's concordance correlation analysis and on the regression line obtained between real and estimated severity, the assessments carried out by all raters were closer to the real value when the proposed scale was used than when the scale was not used (Fig. 2). In most of the studies involving the validation of scales, raters tend to overestimate the disease severity levels (CAPUCHO et al., 2010; RIOS et al., 2013; FRANCESCHI et al., 2020), which also happened in this scale validation. However, this tendency decreased when the scale was used (Fig. 2).

Using the proposed SAD set, $80 \%$ of the variables analyzed were significant, and their values $\left(r=0.93^{*}\right.$, $C B b=0.93^{*}, u=0.36^{\mathrm{ns}}, v=1.12^{*}, \rho c=0.87^{*}$, Fig. $\left.2 \mathrm{~b}\right)$ were closer to an accurate measurement $(r=1, C b=1, u=0, v=1$, $\rho c=1)$ than when the scale was not used $(r=0.85, \mathrm{C} b=0.87$, $u=0.47, v=1.30, \rho c=0.47$, Fig. 2a). Furthermore, Lin's concordance correlation coefficient analysis $(\rho c)$ was closer to 1 (one) when the scale was used, for $80 \%$ of the raters (data not shown).

Thus, the proposed scale improved the accuracy and precision of the estimates, and it is therefore a useful method for assessing the severity of dieback in eucalyptus in epidemiological studies and breeding programs. (a)

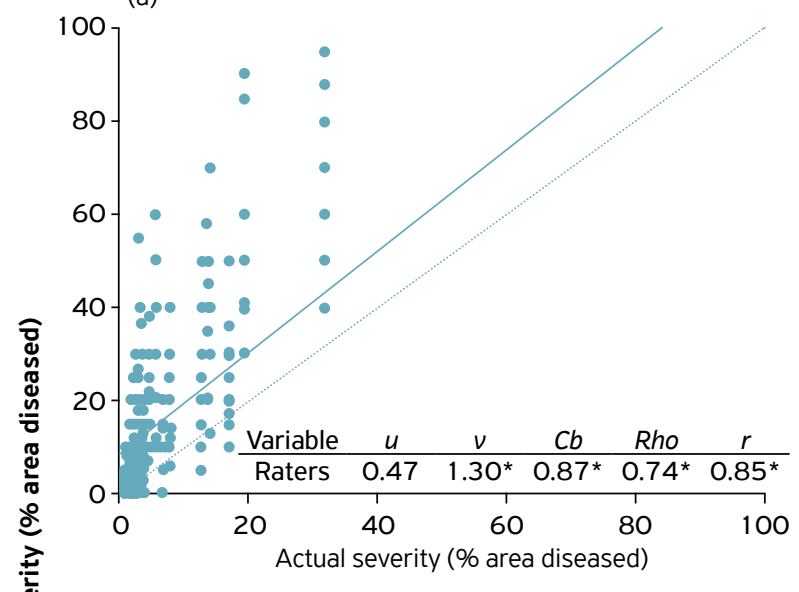

(b)

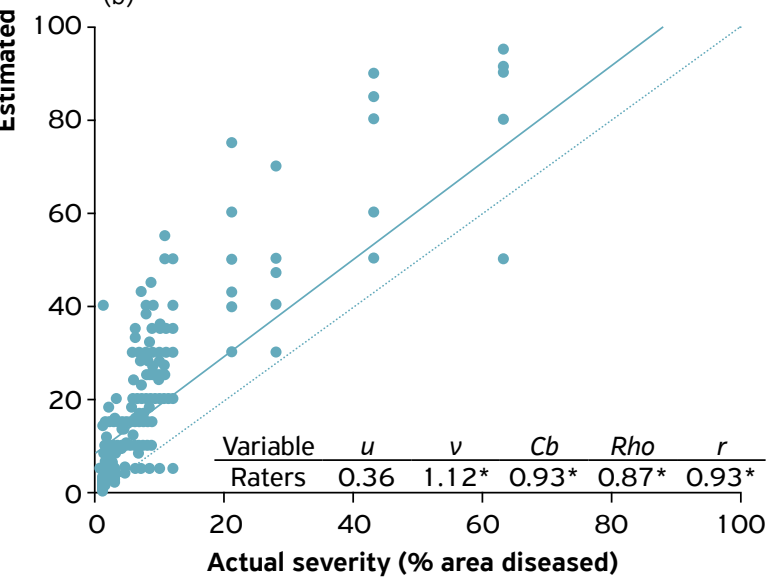

Figure 2. Relationship between actual and estimated bacterial blight (Erwinia psidii) severity on eucalyptus (Eucalyptus grancam $\times$ Eucalyptus urophylla) leaves and branches without (a) and with (b) the use of a standard area diagram (SAD) set for 40 diseased trees, according to ten raters. The solid line represents the best fit. The dashed line represents the hypothetical total agreement between actual and estimated severity. $r=$ Correlation coefficient, $C b=$ Correction factor, $u=$ Location bias or height shift, $v=$ Scale bias or slope shift, $\rho c=$ Lin's concordance correlation coefficient combines both measures of precision $(r)$ and accuracy $\left(C_{b}\right)$ to measure agreement with the true value.

ACKNOWLEDGEMENTS: Not applicable.

FUNDING: Not applicable.

CONFLICTS OF INTEREST: The authors declare no conflict of interest. The founding sponsors had no role in the design of the study; in the collection, analyses, or interpretation of data; in the writing of the manuscript, and in the decision to publish the results.

ETHICAL APPROVAL: Not applicable.

AVAILABILITY OF DATA AND MATERIAL: All data generated or analyzed during this study are included in this published article.

AUTHORS' CONTRIBUTIONS: Conceptualization: Borges Junior, N.; Capucho, A.S.; Lanna Filho, R. Formal analysis: Borges Junior, N.; Capucho, A.S.; Lanna Filho, R. Investigation: Borges Junior, N.; Lanna Filho, R. Methodology: Capucho, A.S. Validation: Capucho, A.S. Writing - original draft: Borges Junior, N. Writing - review \& editing: Capucho, A.S.; Lanna Filho, R. 


\section{REFERENCES}

ARAÚJO, E.R.; RESENDE, R.S.; KREZANOSKI, C.E.; DUARTE, H.S.S A standard area diagram set for severity assessment of botrytis leaf blight of onion. European Journal of Plant Pathology, London, v.153, n. 1, p.273-277,2019.https://doi.org/10.1007/s10658-018-1526-4

ARRIEL, D.A.A.; FONSECA, N.R.; GUIMARÃES, L.M.S.; HERMENEGILDO, P.S.; MAFIA, R.G.; BORGES JÚNIOR, N.; SOUZA, H.P.; ALFENAS, A.C. Wilt and dieback of Eucalyptus spp. caused by Erwinia psidii in Brazil. Forest Pathology, Aberdeen, v.44, n.4, p.255-265, 2014. https://doi.org/10.1111/efp.12087

BOCK, C.H.; POOLE, G.H.; PARKER, P.E.; GOTTwald, T.R. PLANT DISEASE SEVERITY Estimated visually, by digital photography and image analysis and by hyperspectral imaging. Critical Reviews in Plant Sciences, Knoxville, v.29, n.2, p.59-107, 2010. https:// doi.org/10.1080/07352681003617285

BOCK, C.H.; KUOSZU, C.; DEL PONTE, E.M. Accuracy of plant specimen disease severity estimates: concepts, history, methods, ramifications and challenges for the future. Wallingford: CABI, 2016. https://doi.org/10.1079/PAVSNNR201611032

CAIRES, N.P.; GUIMARÃES, L.M.S.; HERMENEGILDO, P.S.; RODRIGUES, F.A.; BADEL, J.L.; ALFENAS, A.C. Bidirectional colonization and biofilm formation by Erwinia psidii in eucalypt plants. Plant pathology, Sutton Bonington, v.69, n.3, p.549-558, 2020. https://doi.org/10.1111/ppa.13136

CAPUCHO, A.S.; ZAMBOLIM, L.; DUARTE, H.S.S.; PARREIRA, D.F.; FERREIRA, P.A.; LANZA, F.E.; COSTA, R.V.; CASELA, C.R.; COTA, L.V. Influence of leaf position that correspond to whole plant severity and diagrammatic scale for white spot of corn. Crop Protection, Lincoln, v.29, n.9, p.1015-1020, 2010. https:// doi.org/10.1016/j.cropro.2010.04.012

CHAI, W.T.; GANSAU, J.A.; ATONG, M.; KADIR, J.; POILI, E.; CHONG K.P. First report of Erwinia psidii associated with papaya dieback disease in Malaysia. Malaysian Journal of Microbiology, George Town, v.13, n. 1, p.20-25, 2017. https://doi.org/10.21161/mjm.89816

COUTINHO, T.A.; BRADY, C.L.; VAN DER VAART, M.; VENTER, S.N.; TELECHEA, N.; ROLFO, M.; PEREZ, C.; WINGFIELD, M.J. A new shoot and stem disease of Eucalyptus species caused by Erwinia psidii. Australasian Plant Pathology, Melville, v.40, n. 1, p.55-60, 2011. https://doi.org/10.1007/s13313-010-0013-y
DOLINSKI, M.A.; DUARTE, H.S.S.; SILVA, J.B.; DE MIO, L.L.M. Development and validation of a standard area diagram set for assessment of peach rust. European Journal of Plant Pathology, London, v.148, n.4, p.817-824, 2017. https://doi.org/10.1007/ s10658-016-1138-9

FRANCESCHI, V.T.; ALVES, K.S.; MAZARO, S.M.; GODOY, C.V.; DUARTE, H.S.S.; DEL PONTE, E.M. A new standard area diagram set for assessment of severity of soybean rust improves accuracy of estimates and optimizes resource use. Plant Pathology, Sutton Bonington, v.69, n.3, p.495-505, 2020. https://doi. org/10.1111/ppa.13148

MACAGNAN, D.; FERREIRA, M.Á.S.V. Movement of the bacterial blight pathogen Erwinia psidii in guava varieties differing in susceptibility. Tropical Plant Pathology, Viçosa, v.43, n.6, p.577-582, 2018 . https://doi.org/10.1007/ s40858-018-0236-y

MONTOYA-ESTRADA, C.N.; COSTA, C.R.; BADEL, J.L.; GUIMARÃES, L.M.S.; ALFENAS, A.C. Root infection and aerial colonization of eucalypt host plants by Erwinia psidii. Tropical Plant Pathology, Viçosa, v.44, n.3, p.251-257, 2019. https://doi.org/10.1007/ s40858-018-0264-7

RIOS, J.A.; DEBONA, D.; DUARTE, H.S.S.; RODRIGUES, F.A. Development and validation of a standard area diagram set to assess blast severity on wheat leaves. European Journal of Plant Pathology, London, v.136, n.3, p.603-611, 2013. https://doi. org/10.1007/s10658-013-0191-x

RODRIGUES NETO, J.; ROBBS, C.F.; YAMASHIRO, T. Uma doença bacteriana da goiabeira (Psidium guajava L.). Summa Phytopathologica, Botucatu, v.9, p.4, 1983.

SILVA, C.F.; UESUGI, C.H.; BLUM, L.E.B.; MARQUES, A.S.A.; FERREIRA, M.Á.S.V. Molecular detection of Erwinia psidii in guava plants under greenhouse and field conditions. Ciência Rural, Santa Maria, v.46, n.9, p.1528-1534, 2016. https://doi. org/10.1590/0103-8478cr20151600

VALE, F.X.R.; FERNANDES FILHO, E.I.; LIBERATO, J.R. QUANT: A software plant disease severity assessment. In: 8th international congress of plant pathology. Anais... New Zealand: Christchurch, 2003. v.8, p. 105. 